\title{
Compaction and Other Sources of Error in Obtaining Sea-Level Data: Some Results and Consequences
}

\author{
Orson van de Plassche*)
}

\begin{abstract}
C-14-dating, sea level, data processing, peat, compaction, contamination, section, Pleistocene North Sea, Netherlands (Hillegersberg, Rijkswegdonk)
\end{abstract}

A bstract: This paper describes observations and results of radiocarbon assays relating to the effect of several sources of error on the time/depth position of data-points. It is shown (a.o.), that the comparability of compaction-free, time/depth data-points from the base of peat beds, representing the onset of peat growth at different levels, can be negatively influenced by compaction of the sampled peat, root contamination, and contamination by older material.

\section{[Kompaktion und andere Fehlerquellen bei der Gewinnung von Seespiegeldaten: einige Ergebnisse und Folgerungen]}

Kurzfassung: Diese Arbeit beschreibt Beobachtungen und Ergebnisse zu RadiocarbonAltersbestimmungen, die mit der Auswirkung verschiedener Fehlerquellen auf die Zeit/Tiefenposition von Datenpunkten zusammenhängen. Es wird (u. a.) gezeigt, daß die Vergleichbarkeit setzungsfreier Zeit/Tiefen-Datenpunkte von der Unterfläche von Torflagen, die das Einsetzen von Moorwachstum in verschiedenen Höhenlagen anzeigen, durch Setzung des beprobten Torfes, durch Wurzelkontamination und durch Kontamination mit älterem Material negativ beeinflußt werden kann.

\section{Introduction}

As a contribution to Project 61 of the I.G.C.P., a large number of new time/depth data-points have been obtained from the mid-western Dutch coastal plain. Of the total of 85 samples, all but one from peat beds, 40 derive from 2 early-holocene river dunes (so-called donken) near Rotterdam: the donk of Hillegersberg and the Rijkswegdonk; 19 from the base of the Lower Peat on the Mid-Netherlands Plateau between Utrecht and The Hague; and 26, including 1 sample of bivalved shells, from the coastal barrier area between The Hague and the former estuary of the Older Rhine (VAn DE Plassche $1979 \mathrm{~b})$. The position of the sampling areas is indicated in figure 1.

The ultimate aim of the investigation has been to establish a representative relative sea-level curve for the (mid-)western Netherlands. In order to refine and/or to provide an explanation for differences between and with existing sea-level graphs (BENNEMA 1954; Van Straaten 1954; Jelgersma 1961, 1966; Louwe Kooljmans 1974, 1976; RoElEVELd 1974) much attention has been paid to the accuracy and reliability of the data; either by avoiding or reducing as much as possible the effect of several sources of error, or, in certain cases, by codating suspected or contaminated samples to obtain an idea of the order of magnitude of the error involved. Some of the observations and results made and obtained in this respect are the subject of this paper.

*) Address of the author: Drs. O. v a n d e P la s s che, Instituut voor Aardwetenschappen, Vrije Universiteit, De Boelelaan 1085, 1081 HV Amsterdam, Netherlands. 


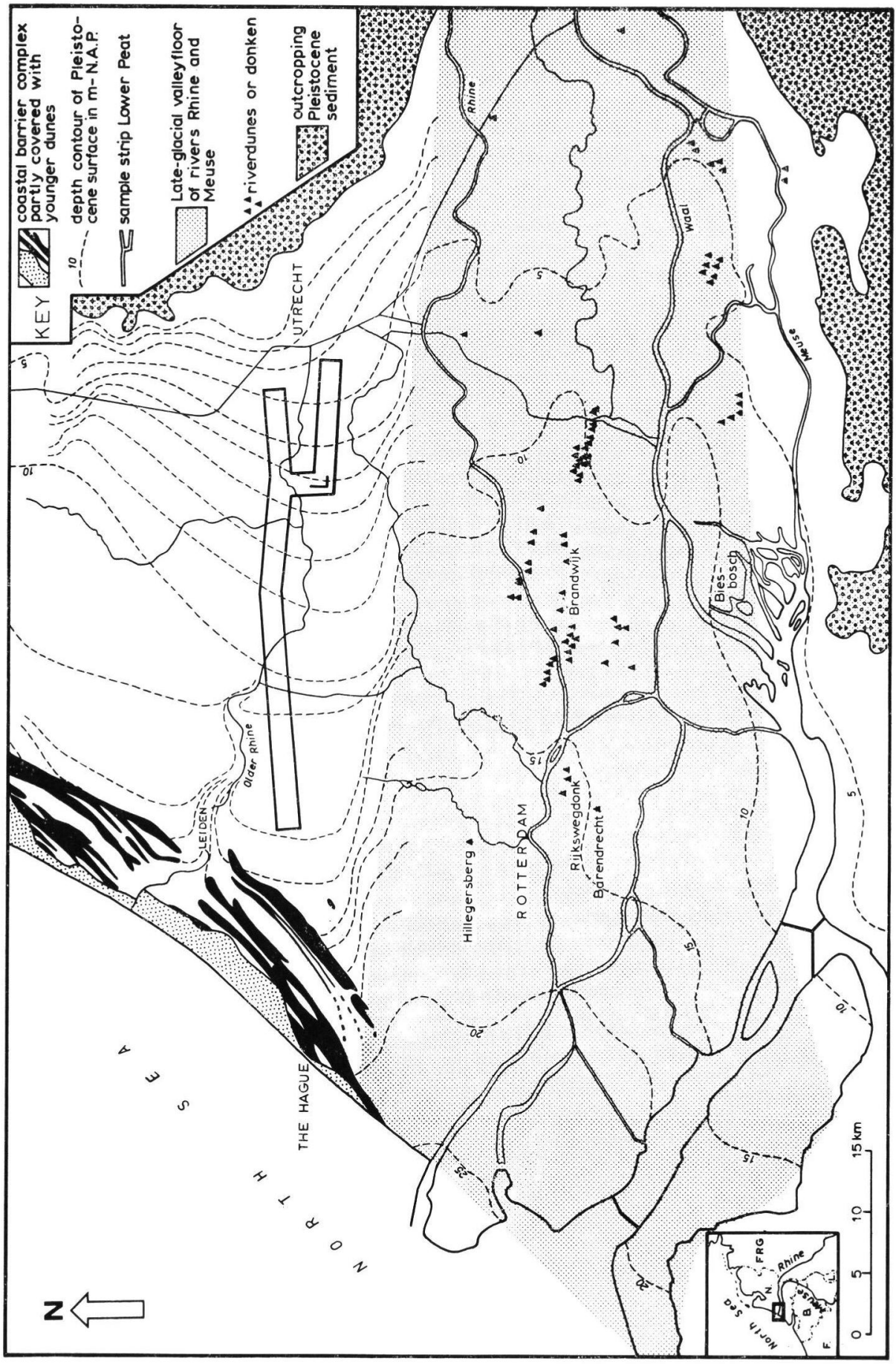

Fig. 1: Map showing the position of the sampling areas mentioned in the text, in relation to their general geological/geomorphological context. [Based on maps from Hageman (1969), JeLGERSMA et al. (1970), Pons \& Bennema (1958), and Verbraeck (1974)]. 


\section{Sources of error}

Of the many possible causes for obtaining an inaccurate or unreliable value for the altitude and, in particular, for the age of a sample, only the following will be discussed:

1. Diachronous boundaries

2. Compaction of the sampled peat

3. Root contamination

4. Contamination by older material

5. Compaction of underlying deposits

\subsection{Diachronous boundaries}

In sea-level studies it is not uncommon to make use of radiocarbon dates, which originally have been obtained for stratigraphical purposes only. For instance, the age of a sample from the base of a peat bed that has been lowered by compaction of underlying deposits, can be connected to the altitude of the bed where it is found to rest on non or much less compactable sediments. Inherent in this procedure is the assumption that the base of the peat bed is isochronous. As is indicated below, this assumption, if not supported by evidence, may lead to considerable errors.

For example: peat growth following a period of sediment deposition can begin (much) later on relatively high and well aerated features such as natural levees when compared to nearby backswamps; when the deposition of a clay bed around a donk is followed by a temporary lowering of the (local) water level, peat formation is most likely to begin at some distance from the dune where compaction of the (thicker) underlying deposits can be expected to reach the highest values. Accumulation of peat on the dune slope does not occur until the water level has risen again. This sequence of events has been depicted schematically in figure 2. A final example may be given. The base of an oligotrophic peat layer, embedded in a body of eu-/mesotrophic peat (fig. 3), has been dated $4400 \pm 60 \mathrm{BP}$

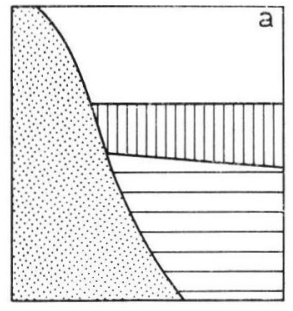

dunesand

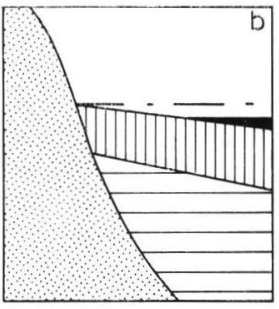

peaty and clayey deposits

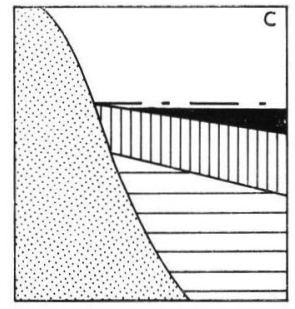

ПIII] clay

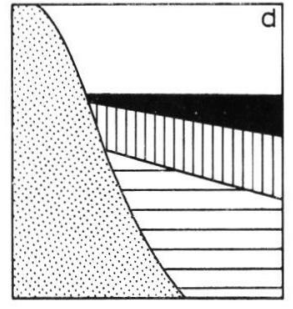

pect

Fig. 2: Schematic representation of events resulting in a diachronic lower boundary of a peat layer (for explanation see taxt).

(GrN 8924). It reaches the donk surface at an extrapolated height of $-1.8 \pm 0.1 \mathrm{~m}$ NAP (Dutch Ordnance Datum). A sample from the underlying Phragmites-Carex peat, taken at the peat/dunesand interface at a depth of $-3.10 \mathrm{~m} \mathrm{NAP}$, gave an age of $4390 \pm 50 \mathrm{BP}$ ( $\mathrm{GrN}$ 7832). These datings prove the base of the oligotrophic peat to be diachronous. The error for the altitude of the time/depth data-point, had the age of $4400 \mathrm{BP}$ been coupled to the value of $-1.8 \pm 0.1 \mathrm{~m} \mathrm{NAP}$, would have been $1.3 \pm 0.1 \mathrm{~m}$ (too high), and would also have led to an erroneous computation of the lowering of the base of the oligotrophic peat bed, and from it the degree of compaction of the underlying column of peat and clay. 


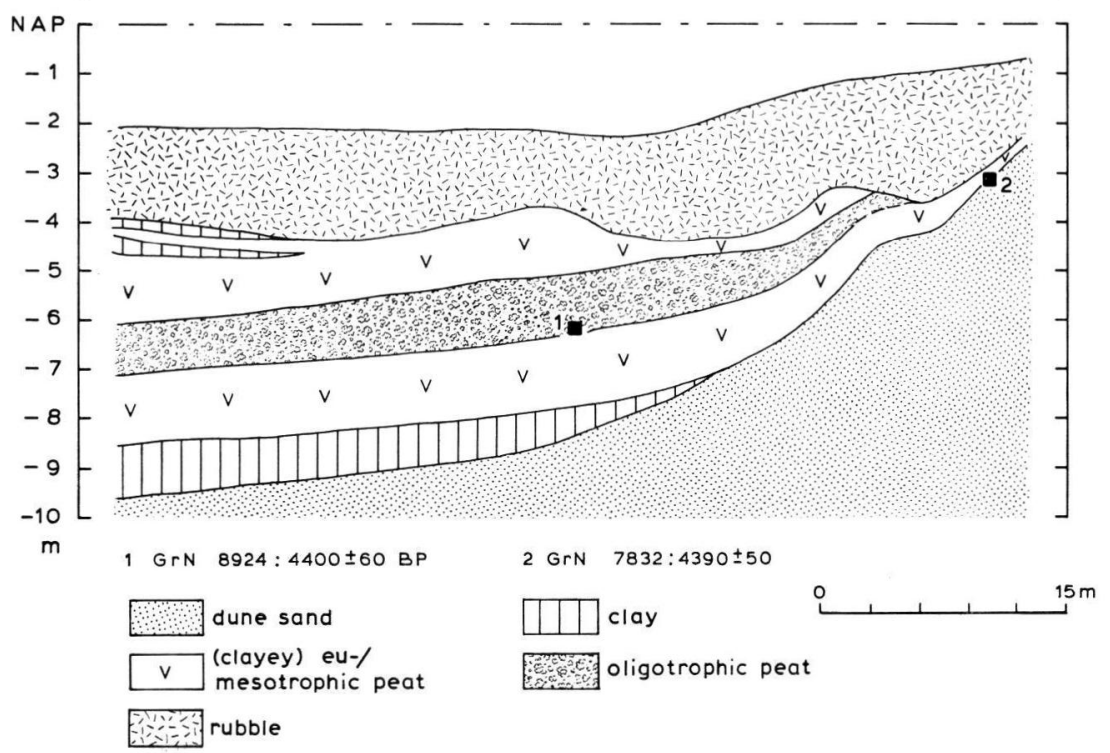

Fig. 3: Section perpendicular to the southern slope of the donk of Hillegersberg, showing the diachronous character of the lower boundary of the oligotrophic peat layer.

The simultaneous growth of eu-/mesotrophic vegetation at and close to the donk, and of a surrounding girdle of oligotrophic plants (Ericaceae, Eriophorum sp.), will have to be taken into consideration when evaluating the height relationship of the level of peat growth (i.e. the ground-water level) at the donk to the water level in the wider surrounding. The oligotrophic vegetation, when in an advanced state of development, will have formed a slightly raised dome, and in between the dune and this low cushion the ground-water level may well have been raised a little relative to the water level outside the oligotrophic peat body.

\subsection{Compaction of peat, sample position and thickness}

The peat on the donk of Hillegersberg and below a depth of ca $8 \mathrm{~m}$ below surface on the Rijkswegdonk, has been subject to considerable compaction due to the weight of the overlying deposits and artificial drainage of the surroundings. This is apparent from the dry and compact nature of the peat and the difficulty of penetrating it with a pointed open tube borer.

In order to determine the rejuvenating effect of compaction on the age of a sample in relation to its thickness, a sample pair from the base of the peat (see core 1 in fig. 4) has been dated. From the very insignificant age difference between sample 1.1 and 1.2 it is concluded that the age-reducing effect of about $88 \%$ compaction (see below) on the age of a sample $1.1+1.2$ would have been entirely negligible. The explanation for this, rather surprising, result is not to be found in a misdating of one of the two peat samples, but, as will be argued below, in the high rate of peat accumulation that occurred at the time/depth interval concerned. 

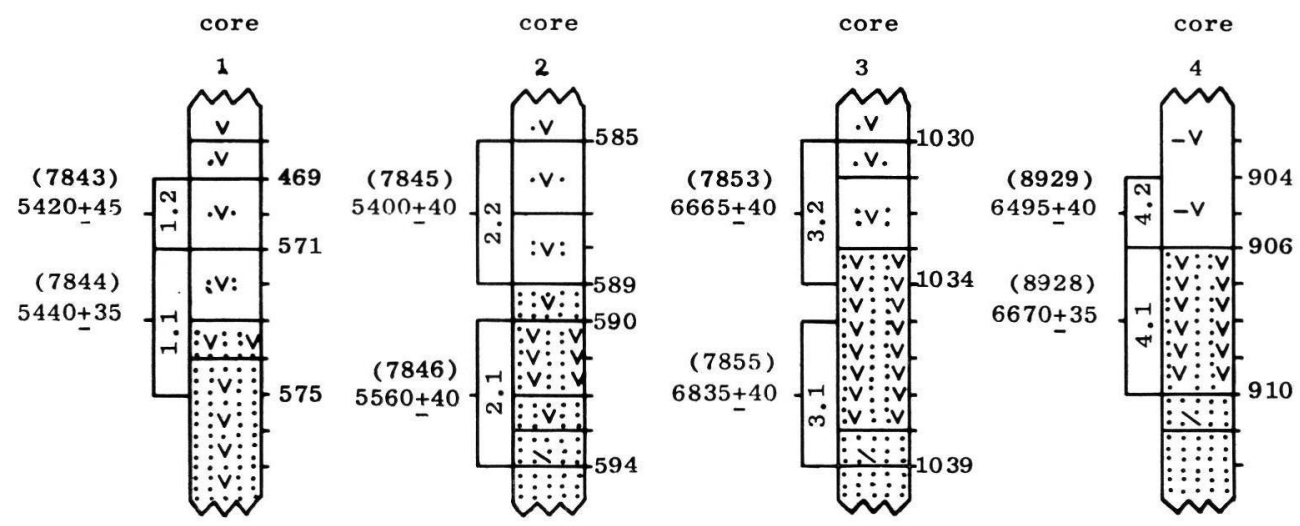

LEGEND
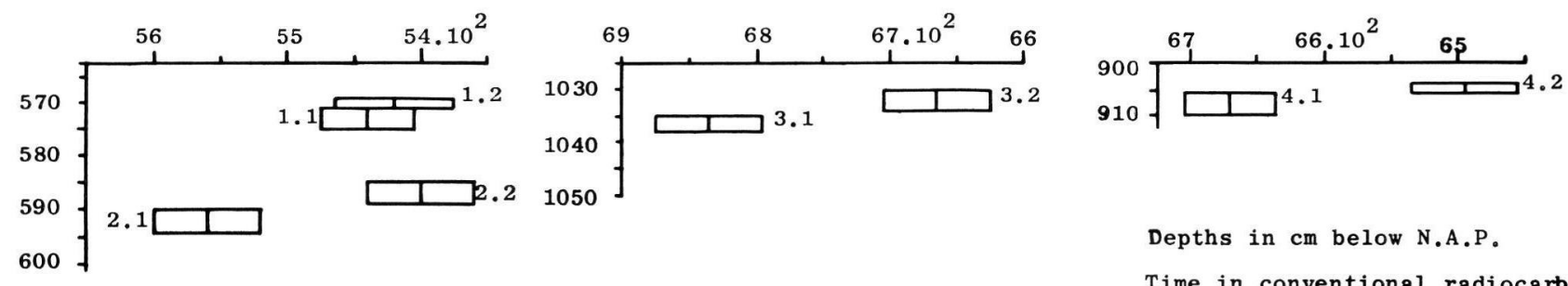

Depths in $\mathrm{cm}$ below N.A.P.

Time in conventional radiocarbon years

Fig. 4: Time/depth plot of sample pairs from cores taken at the donk of Hillegersberg (cores 1, 2, and 3) and at the Rijkswegdonk (core 4). 
In 3 cores from the donken (no. 2, 3, and 4 in fig. 4) the transition from the peat, via (very) sandy peat and (very) peaty sand, to sand, was too gradual to ignore the possibility that the very peaty sand in fact represented the event we wished to date, namely the onset of peat growth on the original dune slope at that spot. In view of the high degree of compaction of the peat, the very peaty sand may originally have been very sandy peat, in which case one would sample too high if the boundary between the very peaty sand and the very sandy peat in the core is taken to represent the former dune surface. While this would not seriously effect the altitude of the data-point, it might have a noticeable influence on the age of it. In each of these three cases, therefore, two samples, immediately above each other (or very nearly so), have been radiometrically dated. The results of the age determinations are given in figure 4.

The age differences for the sample pairs of core 2,3 , and 4 are 160,170 , and 175 radiocarbon years respectively. Although these age differences are not significant at the $99.7 \%$ confidence level, the remarkable internal consistency, together with the low 1 -sigma values for the very peaty sand samples (indicating high carbon content), suggest the age difference between the samples of each pair to be quite meaningful. Thus, in case of a high degree of compaction and a transitional peat-sand boundary, the effect of the compaction should be fully taken into account when determining the vertical position of the sample and the width of the sample interval. In case of doubt, it is advisable to have a pair of samples dated.

Combining the dating results of core 1 and core 2, which have been taken only $1 \mathrm{~m}$ apart, the following reconstruction can be made. Given the same age for the samples 2.2 and 1.2, and assuming a (sub-)horizontal surface of the peat around the donk of Hillegersberg at that time, the present ("compacted") time/depth position of the samples (see fig. 5) can be explained by a reduction of the peat to about $1 / 8$ th of its original thickness (ca $88 \%$ compaction). In figure 5 this value has been applied in reconstructing the original altitude of the top of the samples. A curve connecting the four time/depth boxes

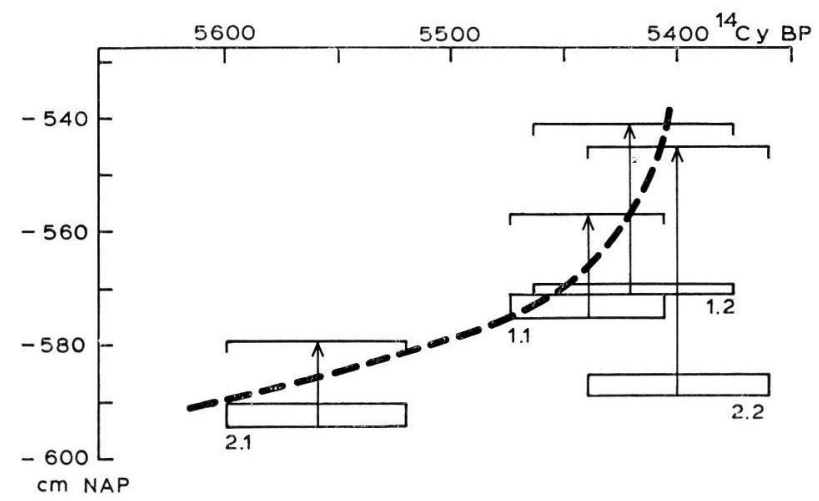

Fig. 5: Time/depth graph showing a distinct increase in the rate of the water level rise (at Hillegersberg). The increase represents the beginning of a Calais II-B transgression sub-phase.

shows that between 5475 and $5400 \mathrm{BP}$ the water level rose much faster than in the period between 5600 and $5475 \mathrm{BP}$. This sudden increase in the rate of the water level rise represents the onset of a Calais II-B transgression sub-phase. The rapid rise in water level has been accompanied by a high rate of peat accumulation, and this explains why, despite the high degree of compaction (possible because of the high pore space and water 
content), the age difference between sample 1.1 and 1.2 is so small. While it is evident that in the case of a highly compacted, but rapidly accumulated peat the width of the sample interval has little effect on the age, it does have a relatively strong effect on the height range of the data-point.

\subsection{Root contamination}

In following the fractionation experiment by SREIF (1971), all Hillegersberg samples have been carefully seperated into a root- and a restfraction with the help of a binocular microscope. As it proved to be very time-consuming to remove all recognizable rootlets, it was decided to subject most of the other samples to a slightly less rigorous pretreatment. From these, without using the binocular microscope, loose bits of wood, all or all larger woody roots and rootlets, Phragmites rhizomes, and (sub-)vertically positioned roots and stems have been removed. The importance of this micro- or macroscopic pretreatment, particularly when dealing with slowly accumulated peat, has been stressed by the author (VAN DE Plassche 1979a), and is well illustrated in the following example.

Most of the samples in the coastal barrier sampling area have been collected close to the former estuary of the Older Rhine (i.e. in the northern part of the beach-plains), as there the levels of sedimentation and peat growth will have been most directly determined by the water levels in the estuary itself. To examine the effect of the factor distance to estuary on the level of peat formation in a beach-plain, samples have been collected along the slope of a dune ridge $5 \mathrm{~km}$ to the south-west of the northern tip of the easternmost beachplain (fig. $6 \mathrm{a}, \mathrm{b}$ ). The uppermost sample, the position of which is indicated in figure $6 \mathrm{~b}$, appeared to be heavily penetrated by roots from the overlying few decimeters of humified peat. All roots and rootlets, recognizable under the binocular microscope, have been removed from the sample. No living rootlets were observed. In order to determine the rejuvenating effect of this root contamination, a second sample, taken at the same depth and $10 \mathrm{~cm}$ to the side of the other sample, has been dated without having been pretreated manually. A check on the presence of living rootlets also was negative. The results of the datings are presented in figure $6 \mathrm{c}$, together with an estimate (based on data to be published) of the level of peat growth at around 3850 and $3350 \mathrm{BP}$ in the northern tip of the beach-plain. From the time/depth position of the data-points it is apparent that, at least between 3900 and $3800 \mathrm{BP}$, the surface of the peat in the beach-plain must have possessed a gentle slope towards the estuary. This phenomenon, which can be explained as the result of a hampered drainage in the central parts of the beach-plain (friction caused by the peat), would have been left unnoticed had the sample (GrN 8865) not been carefully cleared from all recognizable roots and rootlets.

A similar slope of the surface of the peat will have existed towards the estuary of the rivers Rhine and Meuse in the south. On the (inferred) drainage divide of the beachplain peat, about $2 \mathrm{~km}$ south-west of the sampling site (fig. $6 \mathrm{a}$ ), remains of Sphagnum and Eriophorum have been encoutered in the upper part of the peat. This agrees with the decrease in nutrient supply to be expected there.

\subsection{Contamination by older material}

In quite a number of borings the Lower Peat appeared to be seperated from the (podzolised) sand below by a thin layer $(1-4 \mathrm{~cm})$ of black, greasy-like, organic material. As the origin of this material predates the onset of continuous peat accumulation - it has probably been formed in an environment of alternating wet and dry conditions - it would be interesting to know the age difference between a sample of this black, structureless, organic deposit and a sample from the base of the overlying peat. 


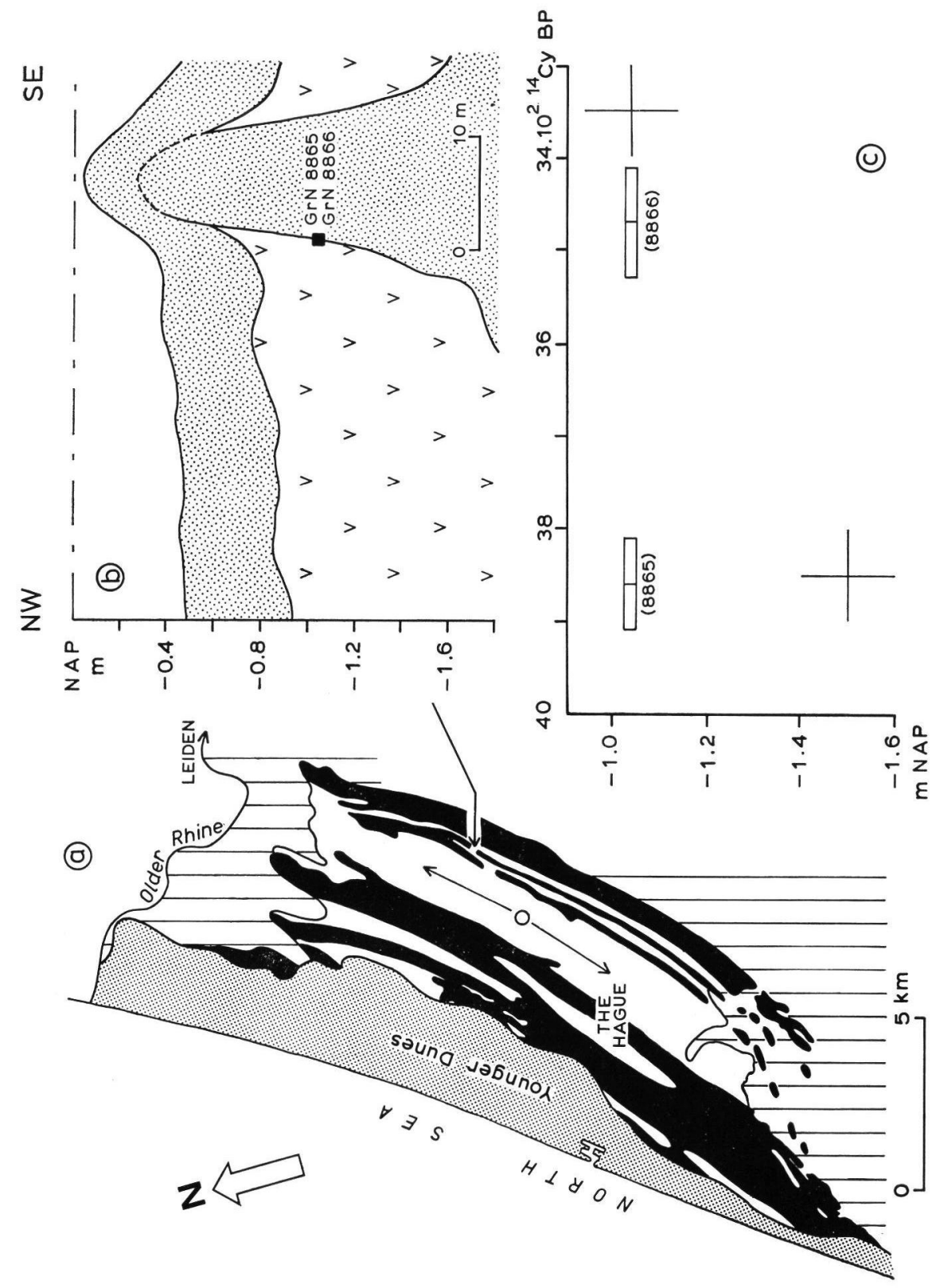

Fig. 6: 6a: Geological map of the coastal barrier complex immediately north and south of The Hague; black: coastal barriers covered by Older Dunes; white: beach-plain peat; vertical hatching: clay of Dunkirk deposits (after JELGERSMA et al. 1970), O: Locality where remains of oligotrophic plants have been encountered in the upper part of the peat; arrows: indicate the direction of the palaeo slope of the beach-plain peat surface.

$6 \mathrm{~b}$ and $6 \mathrm{c}$ : Position and time/depth plot of a sample pair of beach-plain peat (fractionized versus non-fractionized). Crosses in the time/depth diagram represent estimated levels of peat growth in the northern tip of the easternmost beach-plain. 


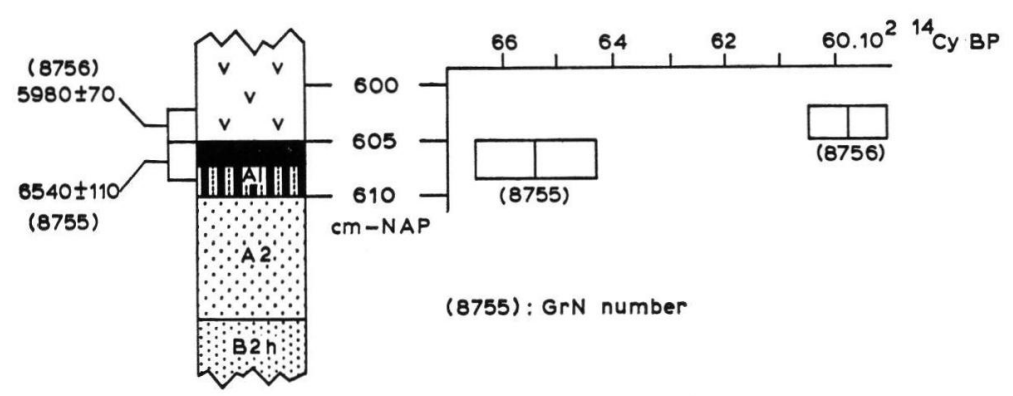

Fig. 7: Time/depth plot of a sample pair, taken in the vicinity of Linschoten, from the base of the Lower Peat and a thin layer of black, structureless, organic material, seperating the Lower Peat from the podzolised sand below.

Figure 7 shows the position of such a sample pair in a core from the vicinity of Linschoten (for location see L in fig. 1). The sample of the black organic layer first had to be carefully cleared from the many roots and rootlets that decended from the peat above. A complete elimination of the smallest rootlets could, however, not be achieved.

From the significant age difference between the two samples, a difference that would even have been larger if all younger rootlets could have been removed, it is apparent that the age of a sample from the base of the Lower Peat will be too old if the sample contains (part of) the black organic material.

\subsection{Compaction of deeper lying sediments}

In the coastal barrier sampling area, the presence of lagoonal clay and peat below the (two) easternmost barrier(s), and of clay(ey) beds intercalated at varying depths in the shallow marine sands (VAN STRAATEN 1965; pers. observations), requires that borings, to determine the presence or absence of compactable layers at potential sampling sites, reach to sufficient depth. (In this respect the suitability of the hand-boring equipment to penetrate sandy deposits and the available manpower are important limiting factors.) The following example may serve to illustrate the point.

A $4 \mathrm{~m}$ deep boring through the top of a small, peat-covered, dune in the centre of the (northern part of the) easternmost beach-plain, showed the sediments to consist only of (shell-bearing) sand. The site was accepted for sampling, until further, less deep borings in the surrounding revealed the presence of a thin band of clay, the variation in heigh of which strongly suggested the dune to have been lowered (fig. 8), apparently by compaction of deeper occurring sediments. A boring to a depth of $6 \mathrm{~m}$ proved that from $3.75 \mathrm{~m}$ onward the sediment is made up of clayey sand, very sandy clay, and many cm's thick clay beds. The amount of lowering of the dune top has been estimated to be at least $0.6 \mathrm{~m}$. This locality has been rejected for taking samples.

\section{Acknowledgements}

I am grateful to Mr. R. Hoogendoorn and his staff of the Boor Technische Dienst (Geological Survey Netherlands, Haarlem) for providing the excellent cores; Dr. W. G. Mook of the Groningen radiocarbon laboratory for dating the samples; Dr. H. Colley for correcting the English text; Mr. H. Sion for drawing the figures and Mr. C. van der Bliek for his photographic assistence. The data presented in this paper form part of an investigation made possible by the Netherlands Organization for the Advancement of Pure Scientific Research (full grant 075-95). 


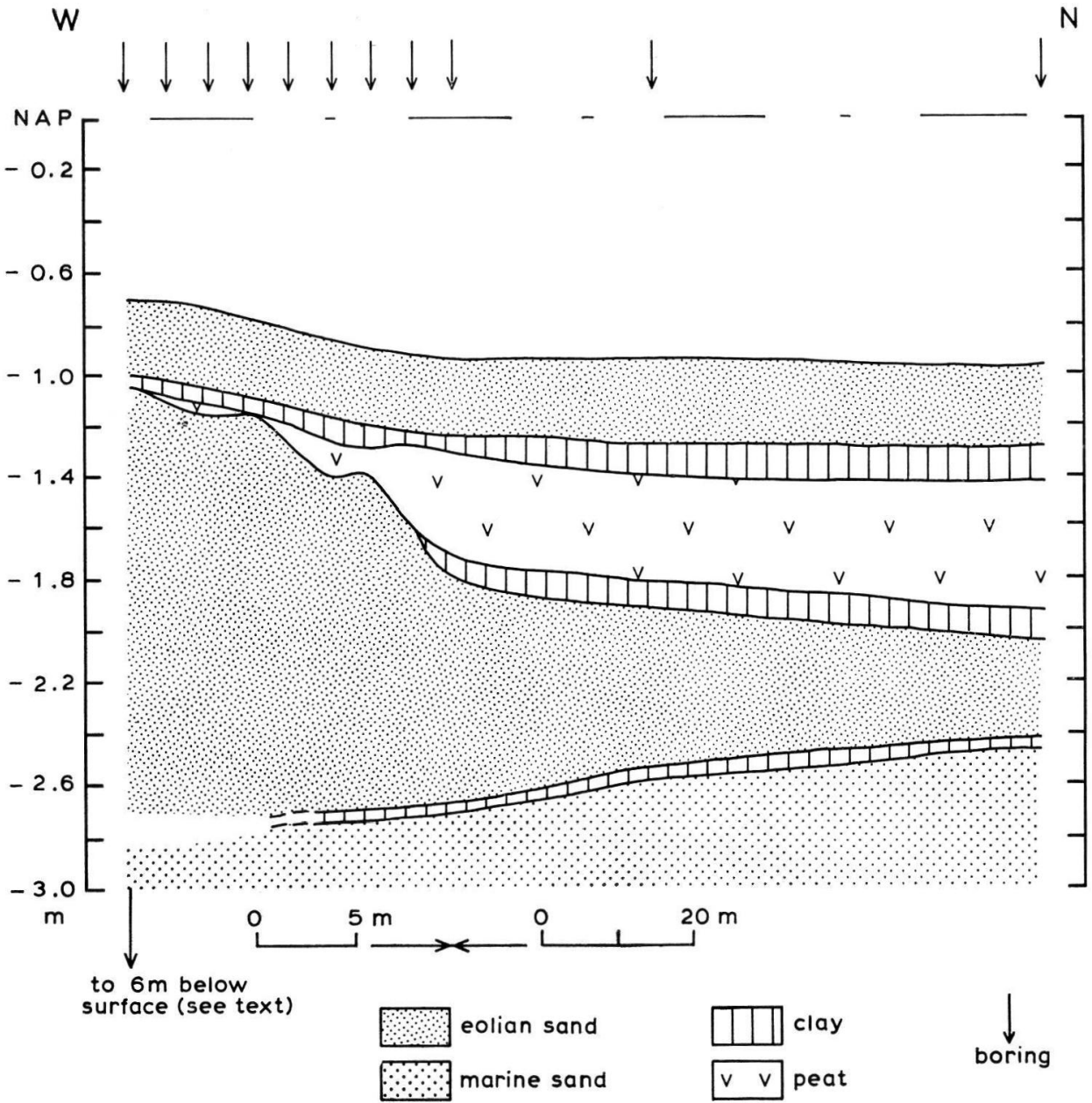

Fig. 8: Section across the northern slope of a small dune in the centre of the (northern part of the) easternmost beach-plain. The dune and its surroundings have been lowered by compaction of deeper lying sediments.

\section{References}

Bennema, J. (1954): Bodem- en zeespiegelbewegingen in het Nederlandse kustgebied. - Diss.: 85 p., 17 fig.; Wageningen.

Hageman, B. P. (1969): The Western part of the Netherlands during the Holocene. - Geologie en Mijnbouw, 48 (4): 373-388, 9 fig.; Rotterdam.

Jelgersma, S. (1961): Holocene sea-level changes in the Netherlands. - Meded. Geol. Sticht., Serie C-IV, 7: 100 p., 50 fig., 3 tab.; Maastricht.

- (1966): Sea-level changes during the last 10.000 years. - In: SAwyer, J. S., ed., World Climate 8000 to 0 B.C.; Proc. Intern. Symp. 18-19 April, 1966; London: 54-71, 10 fig.; London. 
- , de Jong, J., Zagwijn, W. H. \& van Regteren Altena, J. F. (1970): The coastal dunnes of the western Netherlands; geology, vegetational history, and archaeology. - Meded. Rijks Geol. Dienst, Nw. Serie, 21: 94-167, 39 fig., 10 pt.; Maastricht.

Louwe Kooljmans, L. P. (1974): The Rhine/Meuse Delta; four studies on its prehistoric occupation and Holocene geology. - Diss.: 421 p., 124 fig., 27 tab., 16 pt.; Leiden.

- (1976): Prähistorische Besiedlung im Rhein-Maas Deltagebiet und Bestimmung ehemaliger Wasserhöhen. - Probleme der Küstenforschung im südlichen Nordseegebiet, 11: 119-143, 11 fig.; Hildesheim.

Plassche, O. VAN DE (1979a): Reducing the effect of root contamination of peat samples. Oceanis, Fasc. Hors-Séries, 5: 215-218, 3 fig.; Paris.

- (1979b): Sea-level research in the Province of South-Holland, Netherlands. - In Suguio, K., Fairchild, T. R. Martin, L., \& Flexor, J.-M., Ed's., Proc. 1978 Intern. Symp. on coastal evolution in the Quaternary: 534-551, 10 fig.; Sao Paolo.

Pons, L. J. \& Bennema, J. (1958): De morfologie van het Pleistocene oppervlak in westelijk midden-Nederland, voor zover gelegen beneden gemiddeld zeeniveau (N.A.P.). - Tijds. K.N.A.G., LXXV (2): 120-139, 7 fig., 1 map.; Leiden.

Roeleveld, W. (1974): The Groningen coastal district. A study in holocene geology and lowland physical geography. - Diss.: 252 p., 66 fig., 26 tab.; Amsterdam.

Stranten, L. M. J. U. van (1954): Radiocarbon datings and changes of sea-level at Velzen (Netherlands). - Geologie en Mijnbouw, Nw. Serie, 16: 247-253, 4 fig.; 's-Gravenhage.

- (1965): Coastal barrier deposits in South- and North-Holland, in particular in the areas around Scheveningen and IJmuiden. - Meded. Geol. Sticht., Nw. Serie, 17: 41-75, 26 fig., 4 tab., 14 pt.; Maastricht.

Streif, H. (1971): Stratigraphie und Faziesentwicklung im Küstengebiet von Woltzeten in Ostfriesland. - Beihefte Geol. Jahrb., 119: 59 S., 10 Abb., 6 Tab.; Hannover.

Verbraeck, A. in coop. with KoK, H. \& van Meerkerk, M. (1974): The genesis and age of the riverdunes (donken) in the Alblasserwaard. - Meded. Rijks Geol. Dienst, Nw. Serie, 25 (1): 1-8, 12 fig., 2 pt.; Maastricht. 
